\title{
Overuse of Facebook and Academic grades: an Inverse Correlation
}

\author{
Aftab Ahmad Rather \\ Ph.d Research Scholar Department of Sociology, Guru Nanank Dev University Amritsar, Punjab. 143005
}

\begin{abstract}
The emergence of online communication in shape of social networking sites (SNS) has tremendously increased the number of internet users world wide in general and in India in particular. The main reasons behind the tremendous increase in number of social networking site users is availability of all sorts of infotainment under one click. Although all age groups are using various social networking sites inorder to communicate online but the users proportion of facebook is much higher than others. Facebook is a world wide used social networking site with pre designed user friendly pages and latest applications and games due to which the proportion of youth facebook users is higher than other age groups. Facebook is designed in such a way as it develops initially attraction within users to use it and then compels them to over use it hence offshoots addiction within them to be online and to converse online with various know as well as unknown users. Mostly the victim of this addictive online communication of facebook is youth (15-35 years of age) as of their leisure time due to low responsibility in their early dependency periods and unawareness about the impact of its over use on them due to which their various aspects are getting affected in addition to acedamic grades. The impact on acedamic grades is both positive as well as negative but the intensity of later is much higher than former type of impact. This research paper will through light on the impact of use or overuse of facebook social networking site on the acedamic grades or carrier of youth users and will surely help the readers in making a balance between use and overuse of internet in general and facebook social networking in particular.
\end{abstract}

Keywords- Acedamic grades, Facebook, Online Addiction, Online Communication, Social networking sites $(S N S)$

\section{Introduction}

In todays era of computer mediated communication, the popularity of social networking sites is increasing in quality as well as in quantity as these are being used by almost all age groups in order to get connected with known as well as unknown users besides youth college students who reside away from home in hostels. Young people are motivated to register to these sites in order to keep strong ties with their close as well as faraway friends, relatives and to strength ties with new acquaintances and to meet newer people. The worldwide leading social networking website- facebook- provides ample of oppurtunities to its users to connect with known as well as unknown users throughtout the world any time when online that too on comparatively low affordable browsing charges. It is today regarded as world's top most popular and used social networking service (SNS) and website which connects each day millions of people to participate in wide range of activities ranging from online communication and information to establishment of online relations by text as well as voice chats etc. Its use provides users various opportunities to communicate online with friends, friends of friends by sharing events, updating statuses, uploading videos, links, photos apart from sending messages by using internet. Any person who declares himself or herself of 13 years of age or above can register to this site in order to become the registered member irrespective of caste, class, creed, color, sex, race, region and religion. After signing up for it, mostly the users join different or common interest user groups, organized by different organizations such as, workplace, school or college and categorize their friends into different lists on the basis of their affiliation with them. In addition they update their relationship status and hence create an online identity by putting up their profiles online. Like other social networking sites, facebook also provides its registered users formatted / pre designed web pages to update and maintain their profile by entering personal information due to which their interests are being depicted and then associated adds and applications are updated on their walls besides friend suggestion. This allows users to transverse their networks across different people and institutions on the basis of their personal information and hence are mostly exposed to same interest, occupation and ideology users which develops an attractive sound interaction between them and paves way for cyber addiction by compelling them to use facebook for long hours . On daily basis, Facebook is being used by millions of people and plays an important role to show how individuals using facebook understand their world ( $\mathrm{cf}$ : Bourdieu and Wacquant, 2006:161) and how today's average user regards his virtual identity a part of his overall offline identity. It offers free access to users for sign ups, chats, messages, uploads, updates, comments etc and various applications and tools in order to connect more and more people besides provides them every 
means of entertainment and enjoyment of their choices and concerns. Mostly it is being used by youth users who are pursuing their studies in order to share their every moment of life and other related aspects, due to which it directly affects their studies, which in due course negatively affect their academic grades. So, on the basis of above mentioned affect on studies of youth, the study was conducted in order to have a better understanding of using and over using various social networking services in general and facebook in particular. This research paper will be focusing on the impact of social networking site- Facebook on academic grades of youth by exposing them to naked realities of life and associated consequences, which are needed to be addressed at the earliest.

\section{Literature Review}

The Social networking sites and blogs which are being used today with tremendous passion and zeal have transformed the way of using internet in recent years by describing online tools and utilities which allow users for communication, participation and collaboration of information online. Today's young generation especially teens and youth are using technology through innovative ways due to which they are referred as Millennials and have changed the ways we think, work and communicate even though they are in formative years of their life. Today's youth because of these social networking sites have became technology addicts and are quite introverted. Due to such behavior they face very much trouble while making friends, participating around the house and taking part in popular after school activities and don't know how to communicate with their peers and as a result they lack basic social skills because they don't get a healthy amount of interaction which is necessary for social development.

As for as Facebook and academic grades are concerned, Reynol Junco, associate professor at Lock haven University in Pennsylvania, in his study "Too much face and not enough books: The relationship between multiple indices of Facebook use and academic performance" reported that there is correlation between the time spend on facebook and their educational grades, more time spend on facebook leads to low academic grades and vice-verse.

\section{Objectives Of The Study}

The present study is an attempt to understand the consequences of use of facebook especially among the youth with reference to their academic grades, health issues and impact of its over use on real offline relations besides various social problems associated with its use.

\section{Methodology}

The research paper is based on the study on the data collected from 120 youth (15-35 years of age) facebook users ( respondents) who were selected through snowball sampling from main town of District shopian of Jammu and Kashmir state (India) which was selected by the researcher through multi-stage probability sampling by interviewing them through a pre tested interview schedule which consisted of both open and closed ended questions. Amongst 231 villages, Shopian main town was chosen for data collection because of larger population of 14115 (5.31\% of 265960) as per census 2011 than any other place or village of the district besides being a district headquarter and inhabited by heterogeneous classes and castes of population with a different family, economic and academic background. This area was also chosen by the researcher because of accessibility so that the respondents would be interviewed within stipulated time of data collection and research work would be carried out with ease and the objectivity of the research work would be maintained.

\section{1: Facebook and Academic Grades}

\section{Findings and Summary}

Although facebook is being used by all age groups above 13 but the proportion of students is higher than that of rest occupation/ designation users. It is because of formative years of their life corresponding to non shouldering of responsibilities. Due to their greater inclination a question that arises, does use of facebook affect academic grade of the users as its use is mostly associated with cyber addiction and other related issues and concerns? It is expected that facebook use may effect academic grades in addition to one's personality. The study reflected that the use of facebook affects the acedemic grades to a large extent. The data with regard to impact of facebook on academic grades shows that majority of the respondents (87.50 per cent) are of the view that its use does affect academic grades as users spend most of their time online in browsing this site in order to to remain in contact with other known as well as unknown users (Table 1.1) while as very less proportion of the respondents (12.50 per cent) regard its use not to effect academic grades. 
Table 1.1

Impact of Facebook on academic grades

\begin{tabular}{|l|l|l|}
\hline Impact on academic grades & Number & Percentage \\
\hline Yes & 105 & 87.50 \\
\hline No & 15 & 12.50 \\
\hline & 120 & 100.00 \\
\hline
\end{tabular}

\subsection{1: Type Of Impact And Reasons}

It is reflected from the above that the use of facebook affects the academic grades of the students but question may be raised about the nature of the effect; whether its use improves or shatters their academic grades as of its multidimensional patterns of usage? The data in this regard reflect that its impact on academic grades is positive as well as negative (Table 1.2-Figure 1.1). However, majority of the respondent (52.38 per cent) among those who associated its use to effect academic grades reported that the use of facebook negatively affect the academic grades of the students users. On the other hand, those who relate its use to improve academic grades constitute 32.38 per cent of the total respondents, while as the proportion of those respondents who uphold the view that its use by students may have both positive as well as negative impact on their academic grades was less comparatively ( 15.38 per cent).

FIGURE 1.1

TYPE OF IMPACT

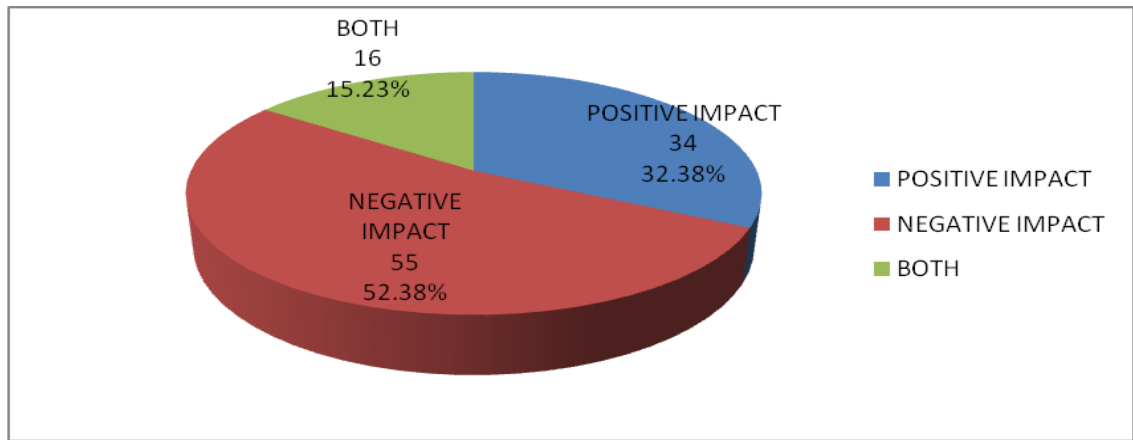

The users put forth multiple views in support of their views with regard to its nature of impact as of dynamic human nature and differential approaches used by people in order to communicate through this service.

\subsection{2: Reasons Of Positive And Negative Impact \\ Positive impact:}

The impact of facebook use on academic grades is positive as it leads users to the acquisition of latest as well as oldest / earlier information regarding various aspects of everyday life by updating them with ongoing happenings about the world. Such view is reflected by 17.14 per cent of the total respondents (Table 1.2). Its use also connects users with high qualified and religious minded persons due to which their academic grades get improved as their knowledge horizon improves and becomes multidimensional ( 8.58 per cent). In addition, contact with subject experts around the world also has a positive impact on academic grades of the respondents as they converse to them any time anywhere and get benefited by their valuable advices and guidelines due to which they get a better insight over the subject from within or outside the country (6.67 per cent).

TABLE 1.2

TYPE OF IMPACT OF FACEBOOK

\begin{tabular}{|c|c|c|c|c|c|}
\hline \multirow[t]{2}{*}{ Impact } & & \multirow[t]{2}{*}{ Reasons } & \multirow[t]{2}{*}{ Number } & \multicolumn{2}{|c|}{ Sex } \\
\hline & & & & Male & Female \\
\hline \multirow[t]{4}{*}{ Positive } & 1 & $\begin{array}{l}\text { Contact with high qualified and religious minded } \\
\text { people }\end{array}$ & $\begin{array}{c}9 \\
(8.58)\end{array}$ & $\begin{array}{c}5 \\
(4.76)\end{array}$ & $\begin{array}{c}4 \\
(3.80)\end{array}$ \\
\hline & 2 & $\begin{array}{l}\text { Acquisition latest as well as oldest knowledge, } \\
\text { information and update one's self with world }\end{array}$ & $\begin{array}{c}18 \\
(17.14)\end{array}$ & $\begin{array}{c}9 \\
(8.57)\end{array}$ & $\begin{array}{c}9 \\
(8.57)\end{array}$ \\
\hline & 3 & Contact subject experts of any corner of world & $\begin{array}{c}7 \\
(6.67) \\
\end{array}$ & $\begin{array}{c}3 \\
(2.86) \\
\end{array}$ & $\begin{array}{c}4 \\
(3.80) \\
\end{array}$ \\
\hline & $\begin{array}{l}\text { Sub- } \\
\text { Total }\end{array}$ & & $\begin{array}{c}34 \\
(32.38) \\
\end{array}$ & $\begin{array}{c}17 \\
(16.19)\end{array}$ & $\begin{array}{c}17 \\
(16.19)\end{array}$ \\
\hline \multirow[t]{2}{*}{ Negative } & 1 & Addiction of it compels to spend less time of books & $\begin{array}{c}25 \\
(23.81)\end{array}$ & $\begin{array}{c}12 \\
(11.43)\end{array}$ & $\begin{array}{c}13 \\
(12.38)\end{array}$ \\
\hline & 2 & Kills and wastes time & 15 & 8 & 7 \\
\hline
\end{tabular}


Overuse of Facebook And Academic grades: An Inverse Correlation

\begin{tabular}{|c|c|c|c|c|c|}
\hline & & & (14.28) & (7.61) & (6.67) \\
\hline & 3 & $\begin{array}{l}\text { Exposes to all illicit material and links of choice and } \\
\text { concern }\end{array}$ & $\begin{array}{c}10 \\
(9.53)\end{array}$ & $\begin{array}{c}4 \\
(3.80)\end{array}$ & $\begin{array}{c}6 \\
(5.71)\end{array}$ \\
\hline & 4 & $\begin{array}{l}\text { Immature ones get exposed to original sins as per their } \\
\text { tendency }\end{array}$ & $\begin{array}{c}5 \\
(4.76)\end{array}$ & $\begin{array}{c}3 \\
(2.86)\end{array}$ & $\begin{array}{c}2 \\
(1.90)\end{array}$ \\
\hline & $\begin{array}{l}\text { Sub- } \\
\text { Total }\end{array}$ & & $\begin{array}{c}55 \\
(52.38)\end{array}$ & $\begin{array}{c}27 \\
(25.71)\end{array}$ & $\begin{array}{c}28 \\
(26.66)\end{array}$ \\
\hline Both & 1 & $\begin{array}{l}\text { Depends on use and utilization of time, can be used to } \\
\text { gain knowledge and can be used to waste and kill time }\end{array}$ & $\begin{array}{c}16 \\
(15.23)\end{array}$ & $\begin{array}{c}8 \\
(7.61)\end{array}$ & $\begin{array}{c}8 \\
(7.61)\end{array}$ \\
\hline Total & & & $\begin{array}{c}105 \\
(100.00)\end{array}$ & $\begin{array}{c}52 \\
(49.52)\end{array}$ & $\begin{array}{c}53 \\
(50.47)\end{array}$ \\
\hline
\end{tabular}

*Figures in parenthesis denote percentage

\section{Negative impact:}

In contrast, its use has its negative impact on academic grades of the student users as its overuse leads to lowering of academic grades. The study in this regard revealed that the majority of the respondents (23.81 per cent) reported that addiction of using facebook compels student users to be online daily for most of the time without any break due to which their studies are affected negatively resulting in downside of the academic grades as they spend less time on studies. The respondents who regard its use only to kill and waste the precious time of users by indulging them mostly in chatting with online friends or users constitute 14.28 per cent of total respondents, followed by those who regard exposure to watch illicit material and links by users as mostly they get inclined to it as the reason affecting negatively the academic grade of the users (9.53 per cent). Some of the respondents hold that its use exposes immature users to original sins as per their tendencies by making them antisocial and aggressive (4.76 per cent).

In addition to above, a good proportion of the respondents ( 15.23 per cent) hold the view that use of facebook by student users affects academic grades both positively as well as negatively. They hold the view that it mostly depends on student users to manage the time of its use as its use can help them to gain knowledge by enabling them to chat with online knowledgeable users while as on the other hand it can be used to waste and kill time by watching porn sites and links which are reflected through different posts of links directly or indirectly, and playing games.

Apart from above, the sex distribution of users show that positive impact for most of the males is contacts with better qualified and religious minded people where as that for the females is contacts with subject experts in any corner of the world. However, the reasons for negative impact for most of the females are addiction of using facebook and exposure to illicit materials and links of choices and concerns. In contrast exposure of immature ones to original sins and killing and wasting of time are the vices of facebook use in the view of the male.

\section{Conclusion}

From the above it may be concluded that the use of facebook has positive as well as negative impacts on academic grades of its users. However intensity of the positive impact is less although it plays a great role in enabling student users to update themselves with latest as well as up-to-date knowledge and information with regard to any issue, concern or subject from world famous subject experts throughout the world. Positively it helps them to be global in their approach and perspective by exposing them to multidimensional aspects of life where in they learn how to act according to perceived situation and scenario besides introducing them to multi religious, multilingual and multicultural communities. In contrast to above the intensity of negative impact on academic grades is higher comparatively than positive one as of its overuse by users and associated addiction. Those who stress upon negative impact consider that academic grades of the student users are affected as they mostly waste and kill their precious time to watch various illicit sites, links and spend less time on studies. The associated addiction of overuse of facebook compels them to chat and converse through facebook till late night with their preferred chat mates due to which their inclination to be online for most of time increases and study time decreases. So it is evident from the findings of the study that there is mostly an inverse relation with the overuse of facebook and academic grades as more time spend on facebook leads to low academic grades and other associated issues and concerns. So, in this regard it may be perceived that the much independence given to young ones without any check with regard to use of facebook may indulge them in its addiction due to which their academic grades or level may be under a threat. Hence, it is suggested that a supervision is needed to student facebook users by mature ones with regard to its proper usage, so that they may be protected from vices of its overuse. 


\section{Acknowledgement}

I cordially thank Allah subhanawatallah for His blessings on me throughout this research work and my parents for emotional and psychological support. I would like to acknowledge my gratitude to my Supervisor Prof. Dr. M.S. Gill for his scholarly guidance, valuable criticism and showing his faith and confidence in me and other faculty members of Deptt. Of Sociology (Guru Nanak Dev University, Amritsar), besides my relatives and friends.

\section{References}

[1]. Acquisti, A. and Gross, R. 2006. Imagined communities: awareness, information sharing and privacy protection on the Facebook. In Proceedings of the 6th Workshop on Privacy Enhancing Technologies (Cambridge, UK, 2006).

[2]. Aydurmus, Didem (2010). An introduction to Facebook's Nationalistic discourse and its practice. Seminar paper, Druck and Bindung: Books on Demand GmbH, Germany. empowerment in anchored relationships" , Journal on Computers in Human Behaviours, 24(5), 1816-1836

[3]. Giddens, Anthony (2006). Sociology. Polity Press, Cambridge.

[4]. Mohanty, Jagannath (2007) Adult and Non-Formal Education. Deep and Deep Publications

[5]. Newson, Alex; Houghton, Deryck \& Patten, ustin (2009). Blogging and other Social Media: Exploiting the Technology and protecting the enterprise. Gower Publishing Limited, England. Pvt.Ltd, Delhi.

[6]. Rather, Aftab (2012), Impact of facebook - A social networking site on Indian youth: A study of district shopian of Jammu and Kashmir (India)., Guru Nanak Dev University, Amritsar, M.Phil dissertation (unpublished).

[7]. Turkle, S. (1995). Life on the screen: Identity in the age of the Internet. New York: Simon \& Schuster.

[8]. Walther, J., Van Der Heide, B., Kim, S., Westerman, D., and Tong, S. (2008). The Role of Friends' Appearance and Behavior on Evaluations of Individuals on Facebook: Are We Known by the Company We Keep. Human Communication Research, 34(1):2849.

[9]. Wells, Tina, (2011). Chasing youth culture and getting it right. John wiley \& sons, Inc, Canada

[10]. Zakahi, W.R., Christophel, D and Jordan, F. (1993). Social adjustments to first semester of college : communication appreh ension and social network development among college students. Communication research reports 16, pp. 550-556.

[11]. Zhao, Shanyang ; Grasmuck, Sherri; Martin,Jason, (2008). Identity construction on Facebook: Digital empowerment in anchored relationships. Temple University, United States. 